\title{
THE DIGNITY OF THE STATE SUPERINTENDENCY IN THE STATE'S DEVELOPMENT.
}

\section{By Albert M. Deyoe.}

We live in a great State, rich in promise for the future. Bounded on two sides by two of the largest rivers of our continent, with a soil whose fertility wearies not in yielding abundant harvests, and with continental systems of railways to bear our products to the markets of the world. But Providence gave to Iowa a choicer blessing than river or soil or railroad. From the states located to the eastward eame the best men and women to settle our State. The privilege is ours to prove true to our vantage ground, not only to perpetuate their heroic vigor, but to build for larger and better things. Iowa holds the creditable and enviable position of having the lowest percentage of illiteracy of any state in the Union. The laurel was hers by inheritance as she entered statehood; it is I legacy for succeeding generations to merit as a distinction of priceless value. Fortunate, indeed, are we because of the character of the pioneers who settled here, in the quality of the immigrants who have come to us, and in the physical and oceupational conditions in our State. The continuation of comparatively so high a standard of thrift and intelligence among our people will depend first and foremost upon the policy and efficiency of our system of education. Unless the individual is well trained for some occupation in life he is lacking in an essential element in the making of the best class of citizenship, viz., the ability to become self-supporting and capable of supporting those dependent upon him.

But education for efficieney must not take into account merely the utilitarian idea. It must be inspired with idealistic, æsthetic, philanthropic, and spiritual incentives, without which life will not rise to its highest level. The purpose or the function of education appeals to us in this great commonwealth to put within reach of all the children the most generous means for development into useful manhood and woman- 
hood. Young men and young women endowed with the ability and the disposition for work need none of our solicitude concerning the welfare of the State. The 'world owes no man a living, but every man owes it to the world to make a living for himself and those dependent upon him. When we can bring together, embodied in the same individual, right thinking and right doing, sound theory and successful practice, we shall have the well-educated man and the ideal citizen.

Better schools should mean better citizenship. Our boys and girls should not only be prepared to do something well but they should be desirous of doing something well. The disposition to do something well represents the moral side of edueation. Not only the boy who comes from the slums, but the boy who turns the automobile crank is to be dealt with in the training for citizenship. The question of training the boy raised in luxury is just as difficult a problem of solution as the training of the boy raised in poverty. It is just as injurious and unbecoming for a youth to puff out his vitality through a cigarette or a pipe-stem on the college campus as it is in the back alley. Not money, not social caste, not fame, not even scholarship will make men and women worthy of reward. Let us not forget that sympathy for others, purity of living, honesty, industry, reverence, obedience, and respect for law are among the determining forces that will count most in estimating the worth of a life.

The development of the State industrially, and the hope of its eitizenship intellectually and spiritually, depends upon the training of the child. This then represents the responsibility, the dignity of the work of those to whom have been committed the task of shaping the educational policies of the State.

There was a propriety in the selection of the Hon. James Harlan to lay the corner-stone of the beautifully designed Historical, Memorial and Art Building, perhaps not thought of at the time. Many years before the ceremonies connected with the first steps taken toward the erection of the building, James Harlan had been chosen as the first State Superintendent of Schools after the admission of Iowa into the Union in 1846. To this man-one of Iowa's greatest noblemen-was entrusted the duty of laying the corner-stone of our State's great educa- 
tional system, maintained today at the enormous annual expense of over seventeen million dollars. The amount expended is a large sum. But what of it, when we estimate that nearly two and one-eighth times as much money is expended annually in the nation for intoxicating liquors and tobaceo as for the public schools, and almost one and one-half times as much as for education of all kinds. Educational advantages of a generation ago ean not best meet the needs of today, much less the needs of generations to come.

It would be interesting to speak of the development of our State's educational system under the administration of each of the successors to Mr. Harlan, on down through those of Thomas H. Benton, Maturin L. Fisher, Oran Faville, Alonzo Abernethy, and others, but time permits mention only of the one in whose memory we are assembled on this occasion.

Richard C. Barrett lived but half a century. His was a life of wonderful activity and usefulness. In studying the lives of successful men, we are constantly being impressed with the thought that they make the most of their opportunities. They do not wait for a good chance to succeed; they take advantage of such chances as they can get, and make them good.

$\mathrm{Mr}$. Barrett excelled as an instructor and as a school administrator. A teacher of teachers-he never ceased to be a student. He was not satisfied with a superficial knowledge of the subject he attempted to teach. He drank deep from the fountain of information. Some years ago it was my privilege to be a co-worker with Mr. Barrett in a teachers' normal institute in one of the counties in the State. In discussing a disputed question in physiology, Mr. Barrett quoted Gray's Anatomy as his authority. He had consulted the best text; one used by students in surgery and medicine. His study of the principles of education was thorough and exhaustive.

It was his will to work, his purity of living, his Christian fortitude, and his love for humanity that made Superintendent Barrett beloved by all who became acquainted with him. He knew no such thing as failure. He had faith that the mission of the teacher was one of the greatest callings in the world. No wonder that his presence among a body of teachers was an inspiration to them. 
It was through State Superintendent Barrett's efforts that the compulsory attendance law and the law providing for the founding of school libraries were passed by the legislature. Both laws are of special importance and far-reaching in their influence.

Regular and continued effort in school is essential in the education of the child.

It is well that the State through the school attempts to encourage the study of the pure and life-ennobling in literature by children. A squad of boys arrived in one of the small towns in Iowa recently bent on an adventurous deed of some sort. They engaged in a contest among themselves as to who should be chosen leader of the "'gang." They settled upon the plan of "fighting it out" among themselves and in this manner decide who should be made captain. It was found upon inquiry that the reading of bad books prompted these boys to leave home to begin lives of erime. To teach the children how to read without providing them with proper reading material, may prove a dangerous experiment if we apply the test that the kind of literature read by the boy or the girl has a strong influence in shaping his ambition for future activity. More important than the ability to read well is the use made of that ability in contributing to the destiny of the child. In other words, it is more important what a child reads than how well he reads. There are but few schools in Iowa today without a library of at least a few well-selected books.

From Superintendent Barrett's reports I quote the following as exemplifying his ideals in education:

The great need in Iowa is not more schools, but better schools; not more teachers, but better teachers; not a school that fits for teaching, for business, for college, but one that aids students in the preparation for life and its manifold duties. That from right education, the youth may be happier, the home more sacred, the citizen nobler and truer, and the nation stronger.

Truly, Superintendent Barrett dignified the office to which he had been ehosen. 
Copyright of Annals of Iowa is the property of State of Iowa, by \& through the State Historical Society of Iowa and its content may not be copied or emailed to multiple sites or posted to a listserv without the copyright holder's express written permission. However, users may print, download, or email articles for individual use. 